\title{
Ketika perempuan lantang menentang poligami Sebuah analisis wacana kritis tentang wacana antipoligami
}

\author{
UNTUNG YUWONO
}

\begin{abstract}
ABSTR ACT
Critical discourse analysis (CDA) has become a very influential interdisciplinary approach, which views a discourse as a form of social practice. Antipoligamy discourse, as a social practice persisted for a long time ago in Indonesia, offers chalenging discussions in the perspective of CDA. Teun van Dijk, as one of the pioneers of CDA, articulates ideology as the basis of the social representations of groups. Furthermore, he advocates a sociocognitive interface between social structures and discourse structures. Within these views, whenever social groups, including the producers of antipoligamy texts, voice their ideas and feelings, their ideology come up apparently or, otherwise, lies behind language. This paper is an attempt to explain how women formulate their beliefs into a joint statement: by using what ideological discourse production strategies they share their ideology to public. A Joint Statement issued in December 2006, which contains a broad definition of poligamy in negative sense, in fact represents negative other-representation strategy used by its producer.

KEYWORDS

Poligami (poligamy), antipoligami (antipoligamy), perempuan (women), feminisme (feminism), ideologi (ideology), analisis wacana kritis (critical discourse analysis), strategi produksi wacana ideologis (ideological discourse production strategy), pernyataan bersama (joint statement).
\end{abstract}

Analisis wacana kritis, yang muncul sejak menjelang 1980 dan berkembang sebagai jaringan kerja ilmiah sejak awal 1990, memandang wacana sebagai gejala praktis, sosial, dan budaya. Sebagai sebuah ancangan, analisis wacana kritis membagi premis-premis ancangan yang lebih bersifat sosial bagi wacana

UNTUNG YUWONO adalah pengajar pada Program Studi Indonesia, Fakultas Ilmu Pengetahuan Budaya Universitas Indonesia; menyelesaikan Program Doktor Linguistik pada Program Studi Linguistik, Fakultas Ilmu Pengetahuan Budaya, Universitas Indonesia pada tahun 2004 dengan disertasi berjudul "Konstruksi Asindetis dalam Kalimat Bahasa Indonesia”; mempunyai minat yang besar pada bidang morfologi, sintaksis, analisis wacana, analisis wacana kritis, dan pengajaran bahasa Indonesia sebagai bahasa asing. Saat tulisan ini ditulis menjadi pengajar tamu pada Tokyo University of Foreign Studies, Jepang, sejak tahun 2006. E-mail: untungy@yahoo.com. 
(Van Dijk 1997: 2-6). Dengan demikian, wacana dipandang berhubungan dengan konteks secara dialektis serta mengandung fungsi lokal dan global. Fungsi lokal dalam tataran fungsi pragmatis tertentu dalam wacana, seperti menanyakan, mengundang, dan memerintah dan fungsi global dalam tataran fungsi yang lebih luas, yaitu fungsi sosial, politis, dan budaya, seperti memperkenalkan demokrasi dan menuntut pelarangan diskriminasi.

Para ahli analisis wacana kritis, seperti N. Fairclough, R. Wodak, T.A. van Dijk, dan T. van Leeuwen, selalu menyatakan bahwa tujuan utama analisis wacana kritis adalah menyingkapkan keburaman dalam wacana yang berkontribusi pada penghasilan hubungan yang tidak imbang antarpeserta wacana. Sebuah teks, menurut Van Dijk (1997: 9), tidak ubahnya gunung es di pemukaan laut sehingga penganalisis wacana kritis bertanggung jawab untuk menyingkapkan makna-makna yang tersembunyi dalam teks. Secara operasional, pernyataan apapun yang taksa ataupun tidak jelas dalam analisis dijelaskan sehingga terungkap, terutama struktur kekuatan sosial yang tidak imbang. Maksud, pandangan, dan keyakinan sosial, yang dibatasi sebagai ideologi dalam analisis wacana kritis, terkadang disembunyikan di balik perkataan yang dituliskan atau diujarkan. Dengan demikian, penyingkapan ideologi di balik teks itulah yang menjadi tugas utama dalam analisis wacana kritis.

Dalam mencapai tujuan tersebut, analisis tidak hanya bertumpu pada satu ancangan tunggal. Pandangan multidisipliner diperlukan untuk menjelaskan suatu gejala (wacana) yang disoroti secara kritis. Oleh karena itu, meskipun tujuan tersebut tidak pernah berubah, pengembangan kerangka kerja dalam analisis wacana kritis pun melibatkan pandangan multidisipliner yang mampu mengarahkan penganalisis untuk sampai pada penyingkapan makna di balik teks. Van Dijk (2004a, 2004b), misalnya, mencoba mengerangkai ideologi secara sosiokognitif sehingga penganalisis wacana kritis dapat menyingkapkan ideologi berdasarkan strategi penggambaran positif terhadap diri sendiri (positive self-representation) dan penggambaran negatif terhadap pihak lain (negative other-representation), yang diabstraksikan dari wacana politis. Fairclough (1992) menghasilkan kerangka kerja tiga dimensional dalam memahami dan menganalisis wacana, yaitu dimensi wacana sebagai teks, wacana sebagai praktik diskursif, dan wacana sebagai praktik sosial dengan memanfaatkan semiotik-sosial yang dilancarkan oleh Halliday dan Matthiessen (1994). Wodak (dalam Wodak dan Meyer 2001) mengajukan ancangan historis-wacana, yang selalu mengintegrasikan analisis konteks historis ke dalam penafsiran atas wacana. Sementara itu, analisis wacana kritis yang ditawarkan oleh Van Leeuwen (1996) berpusat pada penggambaran aktor sosial dalam wacana dengan memanfaatkan pandangan sosiosemantis dan menjelaskan bagaimana aktor sosial ditampilkan dalam suatu teks.

Dalam tulisan ini saya mencoba mengkaji wacana antipoligami - sebuah wacana yang luas jangkauan problematiknya - terutama dengan memanfaatkan pandangan Van Dijk (2004a, 2004b) sebagai pisau analisis. Seperti analisis wacana kritis pada umumnya, uraian akan diawali dengan latar pokok 
masalah dan selintas uraian tentang kerangka analisis, kemudian dilanjutkan dengan analisis proposisi makro berdasarkan kerangka kerja yang diusulkan Van Dijk (2001), analisis strategi produksi wacana ideologis berdasarkan pandangan Van Dijk (2004a, 2004b), dan simpulan, yang menggarisbawahi hubungan intertekstual data yang dianalisis dengan teks-teks yang lain.

\section{LATAR POKOK MASALAH}

Sebuah wacana mengemban fungsi. Wacana antipoligami mengerangkai pelbagai teks, baik lisan maupun tertulis, yang ditujukan untuk menyatakan ketidaksetujuan terhadap praktik poligami, yang secara denotatif didefinisikan sebagai'sistem perkawinan yang salah satu pihak memiliki atau mengawini beberapa lawan jenisnya dalam waktu yang bersamaan' (Kamus Besar Bahasa Indonesia 2001). Secara praktis di Indonesia poligami dibatasi dalam arti yang sama dengan poligini, yaitu 'sistem perkawinan yang membolehkan seorang pria memiliki beberapa wanita sebagai istrinya dalam waktu yang bersamaan' (Kamus Besar Bahasa Indonesia 2001) karena lembaga perkawinan Indonesia mengizinkan poligini, namun tidak poliandri. Untuk selanjutnya, kata poligami digunakan dalam tulisan ini.

Secara historis, polemik tentang poligami telah muncul seiring dengan perjuangan bangsa Indonesia pada masa kolonial. Setidaknya sejak tahun 1910-an dan 1920-an, perjuangan kaum perempuan Indonesia dalam menentang poligami tertandai dalam sejarah (Locher-Scholten 2003:40). Nasionalisme, di samping kesadaran sebagai manusia yang mempunyai harkat dan martabat, yang mulai mengakar dalam jiwa perempuan Indonesia memicu penentangan perempuan terhadap poligami dalam wujud sistem Nyai, yaitu hidup bersama antara perempuan Indonesia dan orang asing, terutama orang Eropa dan Tionghoa (Locher-Scholten 2003:43). Protesprotes yang disuarakan organisasi perempuan Indonesia ketika itu sudah mengimplikasikan konstruksi gender.

Polemik tentang poligami timbul-tenggelam, namun selalu menjadi isu yang rentan. Setiap kali terjadi peristiwa yang berkaitan dengan poligami, pada saat itulah polemik setuju-tidak setuju terhadap poligami pun muncul. Contoh peristiwa besar yang mengangkat kembali polemik poligami adalah perkawinan Soekarno, presiden pertama Indonesia, dengan Hartini pada tahun 1954. Soekarno ketika itu masih menjalani kehidupan pernikahan dengan Fatmawati. Sebagai reaksi atas poligami yang dilakukan Soekarno, Perwani (Persatuan Wanita Indonesia) menyerukan kembali disusunnya Undang-Undang Perkawinan, yang telah disuarakan sejak tahun 1928 (Wattie 2002). Penyelenggaraan Undang-Undang Perkawinan Nomor 1 Tahun 1974 - untuk selanjutnya dalam tulisan ini disebut UU Perkawinan - tidak meredam perjuangan sebagian perempuan untuk menghapuskan sama sekali poligami karena UU Perkawinan hanya memperketat praktik poligami dalam batas tertentu saja, yaitu di lingkungan pegawai negeri tanpa larangan sama sekali. Demikian juga, setiap kali terjadi praktik poligami ataupun isu perselingkuhan di kalangan tokoh agama yang sedang menjadi panutan, perdebatan, bahkan 
demonstrasi, terjadi, seperti yang terjadi di sekitar poligami Nur Iskandar S.Q., Rhoma Irama, Hamzah Haz, dan, terakhir, A.A. Gym. Teks-teks, baik lisan maupun tertulis, seperti opini, berita, pamflet aksi demonstrasi, siaran pers, pernyataan bersama, debat terbuka, hingga instruksi presiden, dan produk hukum berupa undang-undang, menandai wacana polemik tentang poligami.

Sebagai sebuah wacana yang dilancarkan untuk mencapai tujuan tertentu, wacana antipoligami dihasilkan dengan menggunakan strategi. Strategi yang digunakan oleh penghasil wacana yang satu berbeda dengan yang lain. Jika wacana propoligami dilancarkan pada umumnya dengan berdasarkan kerangka acuan tekstual, seperti kitab suci, wacana antipoligami sebagai wacana kontra atas wacana poligami tentu dapat menggunakan strategi yang sama atau strategi yang lain. Dalam pandangan Van Dijk (2004a, 2004b), strategi produksi wacana berkaitan dengan ideologi penghasil wacana. Jika pada umumnya penghasil wacana propoligami membenarkan poligami berdasarkan firman Tuhan dalam ayat-ayat kitab suci, hal itu berarti bahwa ideologi agamis berada di balik pembenaran itu.

\section{STR ATEGI PRODUKSI WACANA IDEOLOGIS: KERANGKA ANALISIS}

Van Dijk (2004a) membatasi ideologi sebagai sistem keyakinan yang dibagi secara sosial oleh para aktor sosial. Dengan kata lain, keyakinan kolektif menjadi kunci pertama untuk memahami ideologi. Namun, ada pintu berikutnya yang menandai batasan ideologi. Ideologi tidak hanya merupakan keyakinan sosial, namun bersifat lebih fundamental atau aksiomatis. Ideologi mengontrol dan mengarahkan keyakinan pihak lain dalam hubungan sosial, misalnya ideologi rasisme mengontrol perilaku dalam imigrasi - sebagai contoh konkretnya, petugas imigrasi memperketat pengawasan terhadap orang-orang tertentu. Selanjutnya, sebagai landasan sosiokognitif kelompok sosial, ideologi secara bertahap menjadi stabil, diyakini oleh lebih banyak penganut, atau terkadang berubah, tidak diyakini lagi, bergantung pada zaman.

Van Dijk (2004b) kemudian menyatakan bahwa ideologi merupakan dasar aksiomatis penggambaran sosial sebuah kelompok sosial, yang melalui perilaku sosial dan mental (sosiokognitif) tertentu, mengontrol wacana sendiri dan akhirnya melebar menjadi mengontrol praktik sosial kelompok sosial yang lain. Dalam hal ini dapat terjadi kerja sama, koordinasi, persaingan, konflik, atau perjuangan. Dalam konteks perdebatan tentang poligami yang akan dikaji lebih lanjut dalam tulisan ini, pertentangan antara ideologi feminisme dan ideologi patriarki dapat menjadi contoh. Secara historis-kultural, wacana propoligami yang berlandaskan ideologi agamis-patriarkal, yang muncul lebih dahulu dalam praktis sosial, kini menghadapi upaya pengontrolan dari wacana kontra terhadapnya, yaitu wacana feminisme.

Ideologi dapat disamarkan atau disembunyikan dalam teks. Seorang rasis mungkin tidak mengatakan bahwa dirinya rasis sehingga ia menyampaikan pandangan-pandangannya tentang pekerja asing atau imigran, misalnya. 
Dalam teks yang menyembunyikan atau menyamarkan ideologi yang dianut oleh kelompok sosial penghasil teks, penggambaran sosial yang dilakukan oleh penghasil teks itu terhadap kelompok sosial yang lain menjadi hal yang penting. Penggambaran sosial yang demikian merupakan strategi produksi wacana ideologis dalam istilah Van Dijk (2004b).

Strategi penggambaran positif terhadap diri sendiri dan penggambaran negatif terhadap pihak lain merupakan strategi makro semantis (Van Dijk 2004b) - sejajar dengan kedua strategi makro itu, sebelumnya, Hodge dan Kress (1993), telah menyebut strategi biner eufemisme (euphemism) - hinaan (derogatory), yang mengungkapkan ideologi penghasil teks. Oleh Van Dijk (2004b), strategi makro tersebut dikonkretkan dengan strategi yang lebih khusus (moves). Sejumlah 27 contoh strategi yang mengonkretkan strategi makro penggambaran-positif-diri (positive self-representation) dan penggambaran-negatif-pihak lain (negative other-representation) kemudian dipaparkan oleh Van Dijk (2004b), yang di antaranya adalah strategi deskripsi aktor (actor description), yaitu deskripsi tentang siapa dan bagaimana aktor yang dijelaskan dalam suatu teks; strategi pengajuan argumentasi otoritatif (authority), yaitu pengajuan atau penyebutan otoritas, misalnya dalam bentuk penyebutan nama lembaga yang mempunyai otoritas atas suatu masalah; strategi pembebanan (burden/topos), yaitu pengajuan argumentasi tentang beban yang akan dipikul oleh suatu pihak; strategi kategorisasi (categorization), yaitu kecenderungan untuk mengelompokkan orang-orang yang terlibat dalam bahasan; strategi perbandingan (comparison), yaitu pengajuan argumentasi tentang persamaan atau perbedaan tentang sesuatu; strategi pengajuan konsensus (consensus), yaitu pengajuan klaim tentang kesepakatan atau keputusan yang diambil oleh pihak-pihak tertentu; strategi pengajuan sanggahan balik (counterfactuals), yaitu pernyataan atau pertanyaan balik yang dilontarkan kepada pihak lain agar pernyataan atau pertanyaan itu dijelaskan atau dijawab oleh pihak lain itu; strategi pengajuan sangkalan (disclaimers), yaitu pengajuan ungkapan yang mengingkari atau tidak mengakui kebenaran suatu pernyataan; strategi pengemukaan eufemisme (euphemism), yaitu pengajuan pernyataan atau ungkapan yang menghaluskan makna suatu kata, seperti kata yang berkonotasi negatif, atau menghindari penyebutan kata yang jelas-jelas bernilai rasa negatif; strategi pembuktian (evidentiality), yaitu pengajuan bukti-bukti yang tersedia menyangga suatu pendapat - dalam hal ini berkaitan dengan intertekstualitas; strategi pengajuan contoh atau ilustrasi (example/illustration), yaitu pengajuan contoh atau ilustrasi untuk memperkuat pendapat atau memperjelas masalah; strategi perampatan (generalization), yaitu pengajuan pendapat yang umum atas hal-hal yang spesifik; strategi leksikalisasi (lexicalization), yaitu penyebutan kata-kata kunci yang melandasi konsep dan keyakinan suatu pihak; strategi pengajuan ungkapan normatif (norm expression), yaitu pengajuan pernyataan yang berupa norma, prasangka, atau apa yang seharusnya dilakukan; strategi permainan angka (number game), yaitu penyebutan angka-angka sebagai bukti kuantitatif atas suatu masalah; strategi polarisasi (polarization), yaitu pengutuban pihak, seperti kami-mereka, 
yang menjelaskan pihak-pihak yang berlawanan; dan strategi pengorbanan (victimization), yaitu penceritaan tentang kejelekan pihak lain.

\section{"STATEMENT BERSAMA": TEKS DAN KONTEKS}

Jumat, 22 Desember 2006, seperti yang dilaporkan oleh berbagai media massa, dua kelompok perempuan yang bertentangan mengadakan aksi demonstrasi di sekitar Bundaran Hotel Indonesia, Jakarta. Aksi mereka dipicu oleh berita tentang poligami yang dilakukan oleh A.A. Gym, seorang ulama Islam yang tengah populer dan menjadi tokoh panutan masyarakat. Kelompok perempuan pertama, yang mendukung praktik poligami dengan landasan kitab suci, berasal dari Hizbut Tahrir Indonesia (HTI); kelompok kedua merupakan himpunan Lembaga Swadaya Masyarakat (LSM) yang tergabung dalam Jaringan Kerja Program Legislasi Nasional Pro Perempuan - untuk selanjutnya dalam tulisan ini disebut JKP3 - dan yang menolak praktik poligami. Kedua kelompok sama-sama memanfaatkan Hari Ibu, 22 Desember, sebagai momentum untuk mengekspresikan pikiran dan perasaan mereka tentang poligami.

Aksi JKP3 tidak berhenti sampai di tempat itu. Pada hari yang sama, siang hingga sore hari, kelompok JKP3 berkumpul di Gedung Panti Trisula Perwari, Jakarta. Pada klimaks acara, mereka, semuanya perempuan, mendeklarasikan kepada publik Statement Bersama "Poligami Adalah Diskriminasi dan Kekerasan terhadap Perempuan dan Anak" - untuk selanjutnya dalam tulisan ini disebut Statement Bersama, yang dapat dibaca selengkapnya pada Lampiran tulisan ini. Empat puluh nama LSM tertera dalam Statement Bersama sebagai penulis dan penyuara - untuk selanjutnya disebut penghasil Statement Bersama. Setelah itu, teks tersebut kemudian dimuat dalam media massa, termasuk internet. Dalam pemahaman kontekstual, deklarasi Statement Bersama, yang berisi tentang penentangan terhadap poligami oleh para perempuan pada Hari Ibu di Gedung Panti Trisula Perwari dan yang telah menjadi bagian dari wacana publik, mengacu pada perjuangan sebagian perempuan Indonesia dalam menentang poligami.

LSM anggota JKP3 merupakan LSM yang memperhatikan persoalanpersoalan yang menimpa perempuan. Salah satu anggota JKP3, yaitu LBHAPIK (Lembaga Bantuan Hukum-Asosiasi Perempuan Indonesia untuk Keadilan) afiliasi Jakarta, pada tahun 2003 pernah mengeluarkan siaran pers yang isinya senafas dengan Statement Bersama. Adapun JKP3 dibentuk pada tahun 2005 sebagai tanggapan atas diselenggarakannya Program Legislasi Nasional, program yang diadakan oleh DPR bersama dengan pemerintah untuk mengagendakan, membicarakan, dan menyelenggarakan undang-undang yang dibentuk oleh DPR atas persetujuan Presiden (periksa Peraturan Presiden RI No. 61 Tahun 2005 Tentang Tata Cara Penyusunan dan Pengelolaan Program Legislasi Nasional). Tujuan pembentukan JKP3 adalah mendesakkan secara politis agenda program legislasi nasional yang properempuan kepada pemerintah dan DPR. 
Statement Bersama berisikan 36 kalimat hasil kesepakatan ke-40 LSM itu. Karena itu, teks mendapat penamaan Statement Bersama. Statement merupakan jenis teks yang berisikan pernyataan, sedangkan bersama berarti hasil persetujuan bersama. Pernyataan juga dicerminkan dari seluruh bagian teks yang berupa kalimat, termasuk judul dan subjudul, kecuali jenis teks Statement Bersama, tanda tangan, dan nama-nama LSM penulis/penyuara.

Meskipun teks tersebut berjenis pernyataan, pada bagian akhir teks terdapat pernyataan yang secara pragmatis merupakan tuntutan, tidak ubahnya seperti sebuah petisi. Tuntutan diarahkan kepada pemerintah (pembuat kebijakan) untuk mengatasi masalah poligami dan akibat-akibat yang ditimbulkannya terhadap perempuan dan anak - hal itu menunjukkan bahwa LSM-LSM penghasil Statement Bersama itu berada di luar pemerintah. Berikut diuraikan proposisi makro yang termuat dalam Statement Bersama, yang akan dilanjutkan dengan bahasan tentang strategi produksi Statement Bersama berdasarkan kerangka analisis yang dikemukakan oleh Van Dijk (2004b).

POLIGAMI DAN TUNTUTAN REVISI UU PERKAWINAN: ANALISIS PROPOSISI MAKRO DALAM STATEMENT BERSAMA

Topik wacana memainkan peran yang mendasar dalam komunikasi dan interaksi (Van Dijk dalam Wodak dan Meyer 2001:101). Dengan memahami topik, apa yang dibicarakan secara global - makna global - dalam wacana dapat diketahui. Topik merupakan struktur makro semantis yang mewujud dalam setiap informasi terpenting yang termuat dalam teks. Tidak hanya itu, topik juga menciptakan kepaduan teks. Artinya, topik-topik yang mendukung suatu bahasan akan menciptakan kepaduan teks. Dengan demikian, dalam satu teks, dapat saja terdapat lebih dari satu topik. Namun, sebagai makna global, lanjut Van Dijk (2001: 102), topik tidak dapat diamati secara langsung oleh pemerhati wacana, namun dipahami atau ditetapkan secara berproses. Bagaimanapun, terkadang ada peranti wacana yang memberikan petunjuk tentang topik, seperti judul, anak judul, dan simpulan. Untuk menemukan topik wacana, Van Dijk (2001: 102-103) menyarankan upaya penemuan proposisi makro, yang kira-kira merupakan setiap pernyataan penting dalam teks yang mempunyai benang merah untuk disimpulkan dalam tingkat yang lebih tinggi (topik wacana).

Statement Bersama memuat proposisi makro yang diwujudkan secara konkret terutama pada judul (PM1) dan anak judul (PM1, PM2, dan PM3) berikut.

PM1 Poligami adalah diskriminasi dan kekerasan terhadap perempuan dan anak

PM2 Poligami memiskinkan dan merendahkan martabat perempuan

PM3 Revisi UU Perkawinan merupakan salah satu upaya untuk menghapuskan poligami 
Pemuatan tiga proposisi makro yang berurutan dan terbuka sedemikian rupa pada judul dan anak judul berkaitan erat dengan situasi penyampaian teks, yaitu bahwa teks Statement Bersama ditujukan untuk masyarakat luas dan berbicara tentang wacana publik yang sedang hangat-hangatnya diperdebatkan. Agar apa yang dibicarakan dalam teks cepat dipahami oleh masyarakat luas, setiap pokok pikiran dalam teks perlu ditonjolkan.

Ketiga proposisi makro tersebut ditempatkan sebagai bagian yang sejajar dan proporsional dalam teks Statement Bersama. Sejajar berarti sama-sama ditonjolkan dalam teks; proporsional berarti sama-sama ditunjang oleh proposisi penunjang (isi atau uraian penunjang) dalam teks. Jika ketiga proposisi makro tersebut digabungkan, terbentuklah proposisi makro yang lebih tinggi, yang sekaligus menjadi topik teks Statement Bersama. Bergantung pada fokus, formulasi topik berdasarkan rumusan ketiga proposisi makro tersebut dapat berupa

PM4-1 Poligami, yang adalah diskriminasi dan kekerasan terhadap perempuan dan anak sekaligus memiskinkan dan merendahkan martabat perempuan, dapat dihapuskan dengan revisi UU Perkawinan

PM4-2 Revisi UU Perkawinan merupakan upaya untuk menghapuskan poligami, yang adalah diskriminasi dan kekerasan terhadap perempuan dan anak sekaligus memiskinkan dan merendahkan martabat perempuan

Formulasi topik mana yang lebih tepat, PM4-1 atau PM4-2, tidak dijadikan persoalan di sini. Jika judul diperhatikan, PM4-1 mendapat penguatan sebagai topik, yang berarti bahwa poligami menjadi pusat perhatian - dan hal itu tampak dalam uraian tentang poligami yang mendominasi Statement Bersama. Namun, jika urutan penyajian diperhatikan, tuntutan Revisi UU Perkawinan ditempatkan sebagai klimaks pada bagian akhir Statement Bersama. Jika dihubungkan dengan wacana sejenis yang sedang berkecamuk di sekitar penulisan dan penyuaraan Statement Bersama, baik poligami maupun UU Perkawinan mendapat perhatian yang sama. Poligami dan UU Perkawinan bagaikan dua ujung kembar pada dwisula yang menyebabkan reaksi berupa pengemukaan wacana antipoligami dan tuntutan Revisi UU Perkawinan dalam satu paket.

Penulis Statement Bersama mengangkat PM1 sebagai judul pernyataan bersama, dengan rumusan "Poligami Adalah Diskriminasi dan Kekerasan terhadap Perempuan dan Anak". Pemilihan judul dengan kata kunci poligami yang dihubungkan dengan kopula adalah, alih-alih dengan kopula yang lain seperti merupakan dan menjadi, dengan kata diskriminasi dan kekerasan terhadap perempuan dan anak menggarisbawahi maksud yang sebenarnya hendak disampaikan, termasuk nantinya ideologi yang melandasi keseluruhan teks. Meskipun menggunakan kopula adalah, poligami tidak dibatasi dalam arti yang sebenarnya (denotatif), tetapi diidentikkan dengan sesuatu yang lain, 
yang sebenarnya tidak sekelas. Dengan judul yang demikian, pemerhati teks itu langsung dibimbing untuk memahami poligami dalam batasan dan tekanan yang negatif. Tidak hanya itu, judul Statement Bersama yang demikian juga menyiratkan adanya hubungan erat masalah poligami dengan masalah diskriminasi dan kekerasan terhadap perempuan dan anak. Secara singkat, penghasil Statement Bersama melakukan pendefinisian secara luas tentang poligami, yang ditemukan hampir sepanjang teks, yaitu bahwa poligami adalah

(1) diskriminasi dan kekerasan terhadap perempuan dan anak (judul);

(2) persoalan (paragraf kedua);

(3) momok bagi kaum perempuan (paragraf kedua);

(4) kini masih dihadapi perempuan (paragraf kedua);

(5) disahkan dalam Undang-undang Perkawinan tahun 1974 (paragraf ketiga);

(6) dipraktekkan di Indonesia sejak beratus-ratus tahun lamanya (paragraf ketiga);

(7) mengakibatkan penderitaan pada kaum perempuan dan anak-anak (paragraf ketiga dan ketujuh);

(8) mendiskriminasikan kaum perempuan (subjudul);

(9) manifestasi kekerasan pada perempuan dan anak (anak judul, paragraf keenam, dan paragraf ketujuh);

(10) eksis karena budaya patriarkal yang kuat (paragraf keempat);

(11) makin berpeluang merajalela karena sistem hukum dan politik yang didominasi laki-laki (paragraf keempat);

(12) legalisasi penyaluran nafsu (paragraf keempat);

(13) pengentalan dan pemapanan superioritas laki-laki (paragraf keempat);

(14) terjadi di semua lapisan masyarakat dalam segala macam strata sosial (paragraf keenam);

(15) keputusan sepihak dari suami ketika istri tidak mempunyai keberanian untuk menolak (dan tak punya kekuatan untuk melawan) (paragraf keenam);

(16) dilakukan tanpa alasan yang jelas (paragraf ketujuh);

(17) mendorong tingginya tingkat perceraian yang diajukan istri (paragraf ketujuh);

(18) makin memiskinkan perempuan (anak judul dan paragraf kedelapan); dan

(19) merendahkan martabat perempuan (anak judul dan paragraf kedelapan).

Sejumlah definiens, baik berupa kata maupun frasa, yang bernilai rasa negatif tampak dominan dalam kutipan-kutipan tersebut, yaitu persoalan, momok, dipraktekkan, penderitaan, diskriminasi, mendiskriminasikan, kekerasan, budaya patriarkal, didominasi laki-laki, merajalela, legalisasi penyaluran nafsu, superioritas laki-laki, keputusan sepihak, tanpa alasan yang jelas, perceraian, memiskinkan, dan merendahkan. Jika dikategorikan secara retoris, definiens negatif itu terbagi 
atas empat kategori, yaitu WUJUD (persoalan, momok, diskriminasi, kekerasan), CARA (merajalela, dipraktekkan, keputusan sepihak, tanpa alasan yang jelas), SEBAB (budaya patriarkal, didominasi laki-laki, legalisasi penyaluran nafsu, superioritas laki-laki), dan AKIBAT poligami (penderitaan, perceraian, kekerasan, memiskinkan, merendahkan).

Dapat disimpulkan di sini bahwa memperkenalkan definisi poligami secara negatif merupakan fungsi global yang diemban oleh Statement Bersama. Secara tekstual, definisi tentang poligami diberikan dalam teks. Secara kontekstual, pendefinisian negatif tentang poligami tersebut menunjukkan dua hal. Pertama, pendefinisian negatif tentang poligami merupakan strategi penghasil Statement Bersama dalam menghadapi (melawan) pendefinisian positif tentang poligami dalam kecamuk wacana perdebatan tentang poligami. Banyaknya definians negatif dalam kata poligami mengimplikasikan kuatnya argumen yang diberikan oleh kalangan propoligami, yang pada umumnya melandaskan pendapat tentang diizinkannya poligami secara tekstual berdasarkan kitab suci (Alquran). Kedua, bagaimanapun hebatnya perdebatan antara kalangan propoligami dan antipoligami, banyaknya definiens negatif tentang poligami dalam Statement Bersama juga menunjukkan bahwa strategi pendefinisian negatif tentang poligami itu lebih merupakan upaya penjelasan atau penyadaran kepada pemerhati teks daripada ditujukan untuk menyerang secara langsung keyakinan yang dianut oleh kalangan propoligami. Upaya penyadaran tampak jelas pada pemberian fakta yang menjadi bukti tentang kenegatifan poligami, yaitu fakta tentang "banyaknya" korban poligami menurut penghasil Statement Bersama, sebagaimana dalam kutipan berikut.

(20) Dari 106kasus poligami yang didampingi LBH-APIK selama kurun 2001 sampai 2005 memperlihatkan bentuk-bentuk kekerasan terhadap istriistri dan anak-anak mereka, mulai dari tekanan psikis, penganiayaan fisik, penelantaran istri dan anak-anak, ancaman dan teror serta pengabaian hak seksual istri. [...] Sedangkan dari pemberitaan yang ada, poligami mendorong tingginya tingkat perceraian yang diajukan istri (gugat cerai) (Warta Kota, 12/4/03; selengkapnya lihat tabel Kasus Poligami LBH-APIK Jakarta).

Poligami dalam definisinya yang negatif itu kemudian dirangkaikan dengan UU Perkawinan. Sarana penghubung logisnya adalah diskriminasi dan kekerasan terhadap perempuan dan anak, sebagaimana yang tampak dalam PM4-1 dan PM4-2. Dengan kata lain, jika poligami itu merupakan diskriminasi dan kekerasan terhadap perempuan dan anak, UU Perkawinan juga merupakan diskriminasi dan kekerasan terhadap perempuan dan anak. Secara intertekstual, jika dikaitkan dengan pasal-pasal dalam UU Perkawinan, Pasal 3 Ayat 2 hingga Pasal 5 dalam UU Perkawinan mengatur penerapan poligami di Indonesia sehingga Revisi UU Perkawinan yang dituntut oleh penghasil Statement Bersama secara pasti diarahkan pada pasal-pasal tersebut 
demi menghapuskan diskriminasi dan kekerasan terhadap perempuan dan anak - sekali lagi, dari penjelasan ini erat kaitan wacana antipoligami dan tuntutan Revisi UU Perkawinan dengan wacana tentang diskriminasi dan kekerasan terhadap perempuan dan anak yang boleh jadi merupakan wacana payungnya; namun uraian dalam makalah ini tidak melebar sampai ke sana.

STRATEGI PENGGAMBARAN NEGATIF TERHADAP PIHAK LAIN DALAM STATEMENT BERSAMA

Dalam melancarkan wacana antipoligami, penghasil Statement Bersama menggunakan beberapa strategi ideologis yang menggambarkan berbagai pandangan penulis tentang poligami. Teks tersebut dituliskan dalam konteks perdebatan tentang poligami, antara kalangan propoligami dan antipoligami. Dengan kata lain, terdapat perbedaan pandangan ideologis tentang poligami antara kalangan propoligami dan antipoligami. Pandangan ideologis apa saja yang dikemukakan dalam Statement Bersama, yang dengan sendirinya menjadi lawan atas pendapat propoligami, dapat dipahami dari strategi produksi wacana ideologis itu.

Deskripsi tentang siapa yang menghadapi segala batasan (akibat) yang negatif dari poligami dan siapa yang melakukan poligami sekaligus mendatangkan akibat yang negatif itu merupakan strategi deskripsi aktor yang menjelaskan subjek dan objek dalam poligami. Kutipan berikut menunjukkan pemakaian strategi aktor.

[...] kaum perempuan Indonesia masih berhadapan dengan persoalan sama yaitu poligami

[...] dan bahwa laki-laki adalah pemilik perempuan.

Terhitung 36 kali kata perempuan dituliskan, yang menjadi kata kunci terbanyak dalam Statement Bersama, sedangkan kata laki-laki dituliskan sebanyak 5 kali. Jumlah kata perempuan yang demikian banyak itu digarisbawahi oleh pernyataan dalam kutipan (21) tersebut, bahwa perempuanlah yang menjadi fokus perhatian karena ialah yang terdera oleh persoalan poligami dan, karena itu, harus dibebaskan dari deraan itu. Penyebab persoalan itu tidak lain adalah apa yang disebutkan dengan keras dalam kutipan (22). Pernyataan laki-laki adalah pemilik perempuan menjelaskan identitas laki-laki, sebagai subjek yang menguasai perempuan. Dengan kekuasaan itu, laki-laki melakukan poligami.

Laki-laki dan perempuan merupakan dua kata kunci ideologis dalam Statement Bersama yang lazim digunakan secara berlawanan dalam wacana gender. Sebagai suatu kajian akademis, kajian gender - yang dibatasi sebagai sebagai diskusi tentang konsep kultural yang berupaya membuat pembedaan dalam hal peran, perilaku, mentalitas, dan karakteristik emosional antara lakilaki dan perempuan yang berkembang dalam masyarakat (periksa batasan gender dalam Tierney et al. 1999) atau secara sederhana sebagai perbedaan 
sosial antara perempuan dan laki-laki - mendatangkan konsensus akademis tentang pembedaan pemakaian pasangan kata pria-wanita dengan pasangan kata laki-laki-perempuan dalam bahasa Indonesia. Oleh kalangan feminis, yang menjadikan gender sebagai salah satu objek kajian utama, kata perempuan digunakan untuk mewakili suatu kelompok sosial yang mengalami tekanan dan peminggiran dari pihak lawannya, yaitu laki-laki, sekaligus berjuang melepaskan diri dari tekanan dan peminggiran itu. Berikut ini sebagai contoh disajikan sebuah kutipan dari media publik yang memberikan penjelasan tentang konsensus pemakaian kata perempuan untuk tujuan menampilkan kesadaran atas realitas kelompok sosial yang tertekan sekaligus mengedepankan kesiagaan, keprogresifan, dan perjuangan kelompok sosial itu dalam menghadapi patriarki (laki-laki).
A Woman Concept of The Oppressed
[...]. As gender being, it is academically accepted as well as part of concensus among feminists that woman is embedded with social construction. In Indonesian the term of woman is perempuan. But due to different understanding about the concept as a gender-being as term of woman, and a biological being as female, Indonesian feminists still use woman-perempuan as women [group] who are constructed patriarchally, [...] While in reality, word of perempuan is continuously used by feminists to promote women's awareness and progressiveness against patriarchy. I guess, within this term, I will use woman-perempuan as a term of human creature who is oppressed/ marginalized as a concept, as well as a reality and a symbol of the ultimate word "the oppressed", and this woman is struggling [...] with the oppression condition, to become aware of their rights by using feminism as a weapon and tool. While female, wanita or betina as a female creature does not yet have the ability to understand that they are being oppressed, $[\ldots]$.
(Umi Lasminah, dalam blognya yang beralamat di www.wartafeminis.wordpress. com, yang diakses pada tanggal 17 Maret 2007 dan disunting seperlunya).

Ideologi feminisme yang melandasi Statement Bersama tidak berhenti sampai di situ. Laki-laki adalah pemilik perempuan tidak hanya menjelaskan identitas laki-laki dan hubungannya dengan perempuan, namun, lebih daripada itu, merupakan keyakinan dasar yang dianut oleh sebagian kalangan feminis, terutama oleh kalangan feminis radikal. Laki-laki adalah pemilik perempuan diyakini oleh sebagian kalangan feminis sebagai merupakan akar masalah yang mengembangkan jeratan berikutnya terhadap perempuan, yaitu budaya patriarki yang kuat, sistem hukum dan politik yang didominasi laki-laki, legalisasi Penyaluran Nafsu melalui produk hukum dan politik, hingga pada akhirnya membuat poligami tetap eksis. Hal tersebut ditunjukkan selengkapnya dalam kutipan berikut.

(23) Budaya patriarki yang kuat membuat poligami tetap eksis.

(24) Sistem hukum dan politik yang didominasi laki-laki semakin memberi peluang poligami merajalela.

(25) Atas nama apa pun poligami tak lebih legalisasi Penyaluran Nafsu.

(26) Semua itu adalah pengentalan dan pemapanan superioritas laki-laki, [...]. 
Keempat pernyataan ideologis itu tertangkap sebagai hujatan terhadap akar masalah, yaitu penganut ideologi patriarki - pemerhati Statement Bersama yang mengenal feminisme mungkin akan teringat pada manifesto-manifesto kalangan kelompok feminis radikal yang bersuara keras terhadap budaya patriarki sejak menjelang 1970-an, yang pada intinya menyatakan bahwa pelaku penindasan terhadap kaum perempuan adalah semua laki-laki yang mengidentifikasi diri sebagai makhluk yang unggul dan istimewa. Secara radikal, penganut ideologi patriarki itu beresensi laki-laki. Sebagai akibat pemakaian strategi penghujatan itu, emosi yang paling tinggi terasa pada bagian Statement Bersama itu. Keempat kata itu merupakan representasi perjuangan ideologi feminisme dalam melawan ideologi patriarki.

Kekuasaan laki-laki atas perempuan tercermin dalam pemakaian kata dan frasa ideologis budaya patriarki, kuat, eksis, didominasi, merajalela, legalisasi penyaluran nafsu, serta pengentalan dan pemapanan superioritas lakilaki yang semuanya bernilai rasa negatif dalam pernyataan-pernyataan itu. Sementara itu, kosakata tetap, semakin, atas nama apa pun, tak lebih, dan semua menjadi pembatas (hedges) yang memberikan tekanan kuat yang membangun perampatan. Eufemisme syahwat laki-laki yang berlebih menjadi Penyaluran Nafsu, dengan huruf $P$ dan $N$ besar, juga menjadi bagian dari strategi penggambaran negatif terhadap penganut ideologi patriarki sekaligus sindiran keras yang mengacu kepada kepemilikan tubuh perempuan oleh penganut ideologi patriarki. Sindiran itu dikembangkan lagi ke arah pelaku hukum dan politik (pemerintah) yang mengekalkan poligami dengan produk hukum UU Perkawinan, yang diacu oleh legalisasi Penyaluran Nafsu. Pemerintah, dengan kata lain, merupakan penganut ideologi patriarki karena dengan setia menjalankan politik patriarki dalam bentuk pelegalan poligami, seperti yang dinyatakan dalam kutipan berikut.

(27) Penolakan terhadap poligami selalu berbenturan dengan budaya dan politik patriarki yang dijalankan dengan setia oleh pemerintah [...].

Strategi leksikalisasi poligami, patriarki, diskriminasi, kekerasan, dominasi, superioritas, macho, dan maskulin memperjelas ideologi feminisme di balik Statement Bersama, bahwa semua itu ada di dalam wacana yang sama dan mengacu pada kekuasaan laki-laki atas perempuan. Namun, sebagai hal yang agak disayangkan, adakalanya penghasil Statement Bersama mengaburkan batasan peristilahan tersebut. Hal itu ditunjukkan dalam kutipan berikut.

(28) Poligami Adalah Diskriminasi dan Kekerasan Terhadap Perempuan dan Anak.

(29) Persoalan poligami dan diskriminasi terhadap kaum perempuan sudah lama menjadi momok bagi kaum perempuan.

(30) Karenaitulah kami nyatakan bahwa: Poligami Mendiskriminasikan Kaum Perempuan, dan manifestasi Kekerasan Pada Perempuan dan Anak. 
Kutipan (28) menunjukkan bahwa poligami identik dengan diskriminasi dan kekerasan terhadap perempuan dan anak - sebenarnya kopula merupakan, alih-alih adalah, jika dipakai akan lebih jelas menunjukkan hubungan antara diskriminasi dan kekerasan terhadap perempuan dan anak. Namun, kutipan (29) menunjukkan keterpisahan poligami dengan diskriminasi terhadap kaum perempuan. Demikian pula, kutipan (28) menunjukkan bahwa poligami identik dengan kekerasan terhadap perempuan dan anak. Namun, dalam kutipan (30), poligami dinyatakan sebagai wujud (bagian dari) kekerasan terhadap perempuan dan anak. Mengapa hal itu terjadi, ada tiga kemungkinan. Pertama, ketakkonsistenan batasan peristilahan kunci merupakan bagian dari negosiasi atau perbedaan pandangan di antara penghasil Statement Bersama. Kedua, ketidakkonsistenan itu terjadi karena semangat penghasil Statement Bersama untuk mengadakan penekanan terhadap sumber-sumber persoalan bagi perempuan yang berkaitan dengan poligami demi penyadaran bagi pemerhati teks itu - sehingga tanpa disadari, penekanan itu menghasilkan perbedaan makna. Ketiga, persoalan teknis, kurang cermatnya penghasil Statement Bersama dalam menggunakan bahasa, yang terbukti pula dengan adanya kesalahan bahasa di beberapa tempat.

Di samping terhadap pemerintah, penggambaran negatif terhadap pihak lain juga diarahkan secara tidak langsung oleh penghasil Statement Bersama terhadap kalangan agamawan, khususnya mufassirin atau penafsir ajaran agama yang propoligami, seperti yang tampak dalam kutipan berikut.

(31) Penolakan terhadap poligami selalu berbenturan dengan budaya dan politik patriarki yang dijalankan dengan setia oleh pemerintah serta juga organisasi yang mengatasnamakan agama.

(32) Karena poligami merupakan keputusan sepihak dari suami ketika istri tidak mempunyai keberanian untuk menolak (dan tak punya kekuatan untuk melawan) - disebabkan: budaya patriarki, agama, ketergantungan ekonomi - maka kebanyakan poligami menyebabkan kekerasan pada perempuan dan anak baik fisik maupun psikis.

(33) Banyak alasan dikemukakan untuk membenarkan praktek poligami, salah satunya untuk mengangkat harkat dan martabat perempuan khususnya perempuan miskin. Pernyataan tersebut justru semakin merendahkan martabat perempuan, karena berarti kaum perempuan tidak mempunyai mampu [sic!] secara ekonomi, tidak mandiri sehingga perlu ditolong dengan cara dikawinkan. Harkat perempuan tidak perlu diangkat apabila Negara dan Masyarakat telah memastikan bahwa tak ada yang lebih rendah dan lebih tinggi di antara perempuan dan laki-laki, melainkan setara.

(34) Berdasarkan itu semua, kami menyerukan kepada semua pihak, khususnya pada pembuat kebijakan: [...] 3. Mengkritisi setiap tafsir ajaran agama yang diskriminatif terhadap perempuan dan sebaliknya perlu segera disebarkan penafsiran ajaran agama yang lebih setara dan adil gender. 
Argumentasi yang membenarkan praktik poligami terutama diajukan dengan landasan acuan tekstual, yaitu apa yang tertulis dalam kitab suci Alquran dan sunah Rasul-(Muhammad)-beristri-lebih-dari-seorang. Surat An-Nisa Ayat 3 merupakan acuan dalam Alquran yang secara jelas membolehkan seorang laki-laki mengambil istri lebih dari seorang, sedangkan Nabi Muhammad beristri lebih dari seorang dengan salah satu tujuannya memerdekakan budak (mengangkat harkat dan martabat orang miskin); dan itulah yang digunakan oleh kalangan propoligami dalam membenarkan praktik poligami. Argumentasi itu ditentang oleh kalangan antipoligami dengan pandangan terhadap acuan yang sama, namun dengan perbedaan sudut pandang. Menurut kalangan antipoligami, termasuk kalangan feminis Islam, Alquran, termasuk ayat di dalamnya yang membolehkan poligami itu, dan sunah Rasul perlu ditafsirkan secara kontekstual, rekonstruktif, dan hidup, berdasarkan tempat dan waktu - penafsiran yang tidak literal dan otoriter terhadap Alquran dan sunah Rasul itu merupakan pandangan yang esensial dalam wacana pembaruan dan liberalisasi Islam (periksa A’la 2003). Karmi (1996:83), misalnya, beranggapan bahwa Alquran pada kenyataannya merupakan dua dokumen dalam satu: satu dokumen yang abadi dan tidak berubah, sementara dokumen yang lain bergantung pada keadaan sosial, dengan patriarkalisme yang termasuk dalam dokumen yang kedua. .

Wacana perdebatan tekstual pun terjadi tidak habis-habisnya, dan penghasil Statement Bersama merasa tidak perlu melibatkan diri secara mendalam dalam wacana perdebatan tekstual itu. Kutipan (31), (32), (33), dan (34) menunjukkan posisi penghasil Statement Bersama, bahwa mereka menentang patriarki dalam agama yang mendatangkan praktik poligami, namun ideologi yang mereka gunakan dalam menentang argumentasi agamis tentang keabsahan poligami itu bukanlah ideologi agamis. Dengan sarana adverbia justru, yang berfungsi menghubungkan ide-ide yang berkebalikan, tanggapan terhadap wacana agamis dalam kutipan (33) disampaikan dalam bentuk strategi penyangkalan yang humanis, berperspektif kesetaraan gender. Alasan pembenaran poligami oleh kalangan propoligami, yaitu untuk mengangkat harkat dan martabat perempuan miskin, dinyatakan tidak benar. Sebaliknya, alasan itu merendahkan harkat dan martabat perempuan dengan menganggap perempuan harus dibantu secara ekonomi dengan cara dikawinkan. Leksikalisasi perempuan, laki-laki, rendah, tinggi, dan setara dalam kutipan (33) itu mencerminkan ideologi feminisme yang diusung oleh penghasil Statement Bersama. Tuntutan "perlu segera disebarkan penafsiran ajaran agama yang lebih setara dan adil gender" dalam kutipan (34) merupakan tuntutan penganut ideologi feminisme untuk menafsirkan ajaran agama tidak dalam kacamata keliteralan yang hanya menyebabkan diskriminasi terhadap perempuan.

Sementara itu, dengan strategi pengorbanan (victimization) yang diarahkan terhadap pelaku poligami (laki-laki), pelaku poligami (laki-laki) memperoleh nilai buruk atau penjelekan - dengan kata lain, menjadi sasaran (korban) pandangan penghasil wacana (periksa definisi pengorbanan dalam Van Dijk 
2004b) - sebagaimana tampak dalam kutipan berikut.

(35) Sebagai masalah yang bukan baru, poligami dipraktekkan di Indonesia sejak beratus-ratus tahun lamanya mengakibatkan penderitaan pada kaum perempuan dan anak-anak.

(36) Karena itulah kami nyatakan bahwa: Poligami Mendiskriminasikan Kaum Perempuan, dan manifestasi Kekerasan Pada Perempuan dan Anak

(37) Karena poligami merupakan keputusan sepihak dari suami ketika istri tidak mempunyai keberanian untuk menolak (dan tak punya kekuatan untuk melawan) - disebabkan: budaya patriarki, agama, ketergantungan ekonomi - maka kebanyakan poligami menyebabkan kekerasan pada perempuan dan anak baik fisik maupun psikis.

(38) Penderitaan tersebut dialami baik terhadap istri pertama juga istri yang lainnya serta anak-anak mereka.

(39) Dari 106 kasus poligami yang didampingi LBH-APIK selama kurun 2001 sampai 2005 memperlihatkan bentuk-bentuk kekerasan terhadap istri-istri dan anak-anak mereka, mulai dari tekanan psikis, penganiayaan fisik, penelantaran istri dan anak-anak, ancaman dan teror serta pengabaian hak seksual istri.

(40) Sedangkan dari pemberitaan yang ada, poligami mendorong tingginya tingkat perceraian yang diajukan istri (gugat cerai) (Warta Kota, 12/4/03; selengkapnya lihat tabel Kasus Poligami LBH-APIK Jakarta).

(41) Poligami Semakin Memiskinkan dan Merendahkan Martabat Perempuan

Penggambaran perilaku pelaku poligami yang konkret tampak pada kutipan (37) dan (39). Kutipan (37) mengimplikasikan egoisme pelaku poligami terhadap istri ("keputusan sepihak dari suami [...]"), sementara wujud konkret kekerasan terhadap perempuan dalam kehidupan berpoligami digambarkan dalam kutipan (39).

Kutipan (39) dan (40) memperlihatkan bahwa strategi pengorbanan yang dipakai dalam Statement Bersama didukung oleh argumentasi otoritatif strategi otoritas (Van Dijk 2004b) - yang memperlihatkan bukti hasil penelitian suatu lembaga bernama LBH-APIK tentang kekerasan terhadap perempuan dan anak dalam kehidupan berpoligami. Bukti otoritatif tersebut disajikan dalam bentuk angka - strategi permainan angka (Van Dijk 2004b) - yang tampak dalam kutipan (39) dari penyebutan jumlah kasus poligami yang didampingi oleh LBH-APIK. Dalam hal ini LBH-APIK digunakan sebagai otoritas yang dipercaya untuk memberikan argumentasi tentang kenegatifan poligami.

Strategi pengajuan argumentasi otoritatif juga diterapkan dengan penyebutan CEDAW (The Convention on the Elimination of Discrimination Against Women), dan UU No. 7 Tahun 1984. CEDAW, yang diterjemahkan 
ke dalam bahasa Indonesia menjadi Konvensi Mengenai Penghapusan Segala Bentuk Diskriminasi Terhadap Perempuan, merupakan dokumen yang dikeluarkan dan disahkan oleh Majelis Umum Perserikatan BangsaBangsa pada tanggal 18 Desember 1979. Indonesia menyetujui dan turut menandatangani konvensi tersebut pada tanggal 29 Juli 1980 dalam Konferensi Sedunia Dasawarsa Perserikatan Bangsa-Bangsa bagi Wanita di Kopenhagen, 29 Juli 1980. Dokumen internasional tersebut pada utamanya berisikan 30 pasal yang mendefinisikan diskriminasi terhadap perempuan dan merencanakan agenda nasional bagi negara-negara peratifikasi konvensi itu untuk mengakhiri diskriminasi terhadap perempuan (CEDAW, yang diakses pada www.un.org/womenwatch/daw/cedaw; Saksena 2004: 10). Salah satu semangat dalam CEDAW, seperti yang dinyatakan dalam bagian Pendahuluan CEDAW, adalah menguatkan keyakinan pada hak asasi manusia yang sama antara laki-laki dan perempuan. Pasal 2 CEDAW yang disebut pada bagian tuntutan kepada pemerintah dalam Statement Bersama berisi tentang penyalahan atas diskriminasi terhadap perempuan dan persetujuan pemerintah atau pembuat kebijakan (states parties) untuk melindungi perempuan dari tindakan diskriminatif apa pun, termasuk upaya menyelenggarakan undang-undang perlindungan bagi perempuan dan sanksi terhadap pelaku diskriminasi. Adapun UU No. 7 Tahun 1984 (yang diakses pada http://www.lbh-apik.or.id/uu-7-84.htm) merupakan undang-undang yang mengesahkan pemberlakuan CEDAW di Indonesia dan ditandatangani oleh Soeharto, Presiden Republik Indonesia ketika itu, pada tanggal 24 Juli 1984. Baik CEDAW maupun UU No. 7 Tahun 1984 digunakan oleh penghasil Statement Bersama untuk menyatakan tesis bahwa pemerintah Indonesia tidak konsisten dalam menghapuskan diskriminasi terhadap perempuan karena poligami masih dibenarkan melalui UU Perkawinan - dalam hal ini wacana tentang perkawinan sebenarnya juga disoroti secara tekstual dari sudut formal-yuridis.

Segala penjelasan di atas mempermudah pemahaman tentang para aktor sosial yang terlibat dalam wacana. Van Leeuwen (1996: 32-34) menyatakan bahwa wacana merupakan praktik sosial yang ditransformasi ke dalam wacana. Aktor sosial merupakan para tokoh yang melakukan atau mengalami praktik sosial itu. Identitas pencerita (narator) dibentuk dari cara-cara bagaimana para aktor lain ditampilkan dalam teks. Dalam hal ini pronomina kami tidak hanya mengacu kepada lembaga-lembaga yang menghasilkan Statement Bersama secara bersama-sama, tetapi juga merupakan aktor sosial penganut ideologi feminisme yang sedang menggalang persaudaraan di kalangan perempuan (sisterhood) dalam perjuangan membebaskan kaum perempuan dari jerat poligami.

Demikian pula, strategi polarisasi kami-mereka dapat dijelaskan lebih mudah. Kerasnya penentangan kami terhadap lingkaran setan "superioritas laki-laki, budaya patriarki dalam sistem hukum, politik, dan agama, serta legalisasi poligami" dengan sendirinya menyinggung aktor sosial lain (mereka) yang berperan dalam lingkaran setan itu, yaitu penganut ideologi 
patriarki, baik dalam wujud laki-laki, pelaku poligami, suami, pemerintah, maupun penafsir ajaran agama. Jika dikembangkan lebih luas lagi, Meskipun hanya muncul lima kali, jika pernyataan dalam kutipan (23), (24, (25), dan (26) dianggap sebagai "roh" Statement Bersama, aktor sosial itu menindas perempuan melalui sistem dan produk patriarki dalam wujud sistem hukum, politik, agama, UU Perkawinan, pasal dalam UU Perkawinan, bahkan poligami itu sendiri.

Dengan menggunakan strategi pengorbanan, penyangkalan, pengajuan argumentasi otoritatif, dan permainan angka tersebut, penghasil Statement Bersama mempunyai landasan untuk mempraktikkan strategi berikutnya, yaitu menyatakan norma: apa yang seharusnya dilakukan untuk mengatasi masalah poligami. Ungkapan normatif yang diajukan dengan tujuan menuntut diarahkan kepada pemerintah - yang pada bagian lain disebut pembuat kebijakan - seperti yang tampak dalam beberapa kutipan berikut.

(42) Dan sudah menjadi tanggung jawab dan tugas pemerintah untuk mendorong dan memberikan kesempatan bagi kaum perempuan, menyediakan dan memberikan fasilitas-fasilitas penunjang kemajuan kaum perempuan seperti: kesempatan pendidikan yang setara, menyediakan klinik kesehatan gratis, layak dan mudah terjangkau bagi ibu dan anak, merevisi semua undang-undang yang mendiskriminasikan kaum perempuan dan masih banyak lagi.

(43) Sebagai negara yang telah melakukan ratifikasi CEDAW (The Convention on the Elimination of Discrimination Againts Women), Pemerintah Indonesia wajib memberikan perlindungan bagi perempuan dari berbagai bentuk diskriminasi, baik di lingkungan keluarga, masyarakat maupun negara.

(44) Pemerintah juga wajib membuat aturan-aturan yang menghapus diskriminasi dan kekerasan terhadap peremuan (Pasal 2 CEDAW).

(45) Oleh sebab itu revisi UU Perkawinan No. 1 Tahun 1974 dengan menghapus lembaga poligami yang disahkan selama ini, merupakan hal yang mutlak harus dilakukan segera.

(46) Berdasarkan itu semua, kami menyerukan kepada semua pihak, khususnya pada pembuat kebijakan: Agar segera membuat langkah-langkah kongkret untuk menghapuskan setiap bentuk diskriminasi dan kekerasan terhadap perempuan, khususnya di bidang perkawinan dengan mengurangi praktek poligami di masyarakat. 2. Mempercepat amandemen Undang-Undang Perkawinan No. 1 Tahun 1974 3. Mengkritisi setiap tafsir ajaran agama yang diskriminatif terhadap perempuan dan sebaliknya perlu segera di sebarkan penafsiran ajaran agama yang lebih setara dan adil gender. 4. Menjadikan UU No. 7 Tahun 1984 sebagai acuan dalam penyusunan setiap kebijakan maupun dalam menyelesaikan kasus-kasus yang berkaitan dengan kehidupan kemasyarakatan, khususnya yang mengenai perempuan. 5 . Menciptakan masyarakat 
yang bebas poligami dan bentuk-bentuk diskriminasi dan kekerasan lainnya terhadap perempuan dan anak.

Ungkapan normatif tersebut tertandai dengan pemakaian verba performatif menyerukan, frasa verbal sudah menjadi, yang menyatategaskan pernyataan Tanggung jawab dan tugas pemerintah adalah mendorong dan memberikan [...]; adverbia harus dan wajib beserta verba sesudahnya; serta konjungsi untuk dan agar beserta verba sesudahnya, yang semuanya mempunyai daya ilokusioner menuntut. Mengenai persoalan poligami, jelaslah apa yang dituntut oleh penghasil Statement Bersama kepada pemerintah adalah menghapus pasalpasal yang mengatur dan membenarkan poligami dalam UU Perkawinan. Caranya dengan mengamandemen UU Perkawinan dan menjadikan UU No. 7 Tahun 1984 sebagai acuan dalam penyusunan kebijakan apa pun mengenai kehidupan sosial. Isu tentang amandemen UU Perkawinan bukanlah isu yang baru. Mengenai pasal-pasal yang menyangkut poligami dalam UU Perkawinan, beberapa organisasi telah mengajukan usulan amandemen UU Perkawinan secara konkret, seperti Kowani, yang pada tahun 2003 dan 2005 pernah mengusulkan izin poligami bagi seorang laki-laki dengan pembatasan hanya dengan dua orang istri, serta LBH-APIK dan JKP3, yang secara tegas menolak poligami dalam pasal apa pun dalam UU Perkawinan (Anshor 2003; "Usulan Amandemen Perkawinan No. 1 Tahun 1974 Berikut Argumentasi-Argumentasinya", yang diakses pada http://www.lbh-apik. or.id/amandemen_UUP-usulan.htm).

Tidak hanya tuntutan memperoleh perlakuan yang adil secara hukum dalam lembaga perkawinan, tuntutan lain dalam Statement Bersama menandai tuntutan yang umum dilontarkan oleh kalangan feminis dalam agenda perjuangan melawan ideologi patriarki (periksa, misalnya, program feminisme radikal dalam manifesto perempuan radikal, yang dapat diakses secara bebas dalam http://www.redletterpress.org/Radical_Women_ Platform.pdf, dan strategi pergerakan feminis sosialis yang ditulis oleh Hyde Park Chapter, Chicago Women's Liberation Union [1972], yang dapat diakses secara bebas dalam http:// scriptorium.lib.duke.edu/wlm/socialist). Dalam kutipan (44) terbaca tuntutan yang demikian, yaitu "mendorong dan memberikan kesempatan bagi kaum perempuan, menyediakan dan memberikan fasilitas-fasilitas penunjang kemajuan kaum perempuan seperti: kesempatan pendidikan yang setara, menyediakan klinik kesehatan gratis, layak dan mudah terjangkau bagi ibu dan anak".

\section{INTERTEKSTUALITAS DALAM WACANA ANTIPOLIGAMI: SIMPULAN}

Bahasan tentang strategi produksi wacana ideologis dalam Statement Bersama memperlihatkan kekompleksan hubungan antarteks dalam wacana antipoligami. Sintesis yang diadakan oleh penghasil Statement Bersama, sekaligus aktor sosial yang menganut ideologi feminisme, merupakan himpunan penggambaran pengalaman sosiokognitif penghasil Statement Bersama dalam proses memahami poligami. Tampak dalam Statement 
Bersama, pembicaraan tentang poligami secara global paling-tidak mengikutsertakan bahasan tentang hak asasi manusia, diskriminasi, kekerasan, budaya patriarki, sistem dan produk hukum, sistem politik dan pemerintahan, agama, hakikat lembaga perkawinan, dan fasilitas kemajuan kaum perempuan. Tentu saja panjang-lebarnya bahasan bergantung pada keyakinan-keyakinan penghasil teks mengenai seberapa jauh persoalan poligami berhubungan dengan persoalan yang lain. Namun, pandangan yang dibawa oleh ideologi feminisme merembes ke banyak arah.

Dari sudut metawacana, jika data wacana antipoligami dipersempit pada awal-awal tahun 2000, makin kuatnya suara feminis di Indonesia dalam menentang poligami merupakan sambutan hangat atas harapan kalangan antipoligami dalam menemukan argumentasi-argumentasi baru tentang kenegatifan poligami. Suhadi (2002), sebagai contoh, mengusulkan agar gerakan perempuan lebih mengedepankan wacana faktual tentang ketakadilan alih-alih melayani argumentasi yang dilancarkan oleh kalangan propoligami dari sudut wacana agama, kecuali jika kritik wacana agama dilancarkan tidak untuk tujuan membuat klaim bahwa agama (Islam) sebenarnya antipoligami. Ia kemudian melihat peluang cerah bagi kalangan feminis untuk menyampaikan suara ketaksetujuan terhadap poligami, seperti yang tampak dalam kutipan berikut.

Diskursus keadilan yang sangat berkembang dan menjadi pusat isu di kalangan gerakan feminisme sosialis, feminisme post-strukturalis, dan feminisme post-kolonial sebenarnya memberikan modal untuk dieksplorasi lebih lanjut dalam kasus ini. Bila memang isu antipoligami ingin diangkat ke publik, gerakan perempuan sudah semestinya harus membuktikan poligami membawa ketidakadilan bagi perempuan, anak, dan keluarga. Pengungkapan fakta sosial yang mendukung diskursus ketidakadilan terhadap perempuan secara "empiris" lebih memiliki kekuatan dibanding reproduksi wacana antipoligami melalui agama.

Selanjutnya, gayung bersambut, muncullah siaran pers yang dikeluarkan oleh LBH-APIK Jakarta pada hari Kamis, 24 Juli 2003, dengan judul "Poligami sebagai Bentuk Kekerasan yang Paling Nyata atas Harkat dan Martabat Perempuan sebagai Manusia di dalam Hukum, Sosial Budaya dan Agama" (dapat diakses pada www.lbh-apik.or.id/srn-pers-poligami.htm). Latar belakang dikeluarkannya siaran pers tersebut adalah isu Poligami Award yang digagas oleh Puspowardoyo, seorang pelaku poligami. Hari Ratifikasi CEDAW dimanfaatkan oleh LBH-APIK sebagai momentum untuk menanggapi isu poligami tersebut.

Isi siaran pers LBH-APIK Jakarta tersebut dapat dikatakan hampir sama dengan Statement Bersama. Ideologi feminisme pun tercermin dalam siaran pers LBH-APIK Jakarta itu, yang disampaikan dalam rumusan yang berbeda, misalnya dalam rumusan sebagai berikut.

Poligami merupakan bentuk penampakan konstruksi kuasa laki-laki yang superior dengan nafsu menguasai perempuan, disisi lain faktor biologis/seksual juga mempengaruhi bahkan demi prestise tertentu. Namun yang nampak dari kesemuanya 
itu bahwa poligami telah menambah beban kesengsaraan perempuan terhadap sekian banyak beban yang sudah ada, dan jika itu kenyataannya maka poligami adalah konsep penindasan terhadap perempuan yang tidak berpihak kepada rasa kemanusiaan dan keadilan.

Selain itu Poligami juga merupakan bentuk subordinasi dan diskriminasi terhadap perempuan, hal mana di dasarkan pada keunggulan/superioritas jenis kelamin tertentu atas jenis kelamin lainnya; Pengakuan yang absah terhadap hirarki jenis kelamin dan pengutamaan privilis seksual mereka atas yang lainnya; Ketentuan ini sangat bertentangan dengan prinsip-prinsip persamaan, anti diskriminasi serta anti kekerasan yang dianut dalam berbagai Instrumen Hukum yang ada.

Statement Bersama, yang ditulis pada akhir tahun 2006, menggaungkan kembali isi siaran pers LBH-APIK Jakarta tersebut dan dengan proposisiproposisi makro yang sama. Hal yang terutama membedakan adalah aktor sosial penghasil teks, yang tidak hanya satu organisasi dalam penulisan Statement Bersama, tetapi kumpulan organisasi di bawah JKP3, termasuk LBH-APIK di dalamnya. Atas dasar persamaan yang besar dalam kedua teks tersebut dan dengan asumsi bahwa Statement Bersama merupakan edisi kedua dari siaran pers LBH-APIK Jakarta, LBH-APIK dapat dianggap sebagai anggota kelompok ideologis yang lebih kuat, meminjam istilah Van Dijk (2004a), dalam JKP3.

Akhirnya, JKP3 tidak lain merupakan wadah hasil penggalangan persaudaraan organisasi perempuan (sisterhood). Perempuan yang beraksi dalam kelompok atau jaringan kerja yang lebih besar diyakini dalam feminisme mempunyai kekuatan sosial yang lebih besar, seperti yang tampak dalam kutipan yang berikut.

We have come to understand that only through an organized collective response can we fight such a system. Sisterhood thus also means to us a struggle for real power over our own lives and the lives of our sisters. Our personal relations and our political fight merge together and create our sense of feminism. Through the concept of sisterhood, women have tried to be responsive to the needs of all women rather than a selected few, and to support, criticize and encourage other women rather than competing with them. (Hyde Park Chapter, Chicago Women's Liberation Union [1972], yang diakses pada http://scriptorium.lib.duke.edu/wlm/socialist).

\section{DAFTAR PUSTAKA}

A'la, Abd. 2003. Dari Neomodernisme ke Islam Liberal: jejak Fazlur Rahman dalam Wacana Islam Indonesia. Jakarta: Paramadina.

Anshor, Maria Ulfah. 2003. "Poligami dalam UU Perkawinan: perlu sanksi hukum", (www.kompas.com), diakses 13 Oktober.

CEDAW, (www.un.org/womenwatch/daw/cedaw).

Fairclough, N. 1992. Discourse and social change. Cambridge: Polity.

Halliday, M.A.K. dan Christian Matthiessen. 1994. An introduction to functional grammar. Cetakan kedua. London: Arnold. (Cetakan pertama 1984). 
Hodge, B. dan G. Kress. 1993. Language as ideology. London/New York: Routledge.

Hyde Park Chapter, Chicago Women's Liberation Union. 1972. “Social feminism: a strategy for the Women's Movement, (http://scriptorium. lib.duke.edu/wlm/socialist).

Karmi, Ghada. 1996. "Women, Islam and Patriarchalism", di dalam: Mai Yamani (ed.), Feminism and Islam: legal and literary perspectives, hlm. 69-85. Berkshire: Ithaca Press.

Lasminah, Umi. 2007. "A woman concept of the oppressed", (www. wartafeminis.wordpress.com), diakses 17 Maret.

LBH-APIK. 2003. "Poligami sebagai bentuk kekerasan yang paling nyata atas harkat dan martabat perempuan sebagai manusia di dalam hukum, sosial budaya dan agama", Siaran Pers LBH-APIK Jakarta, (www.lbh-apik. or.id/srn-pers-poligami.htm).

Locher-Scholten, Elsbeth. 2003. "Morals, harmony and national identity: 'Companiate feminism' in colonial Indonesia in the 1930s", Journal of Women's History (Winter): 14, 4.

Saksena, Anu. 2004. Gender and human rights. Delhi: Shipra Publications.

Suhadi. 2002. "Agama, budaya, dan wacana poligami", Kompas 16 September.

Tierney, Helen (ed.). 1999. Women's Studies Encyclopedia Vol. I. NewYork: Green Wood Press.

Tim Penyusun Kamus Pusat Bahasa. 2001. Kamus Besar Bahasa Indonesia. Edisi Ketiga. Jakarta: Balai Pustaka. (Edisi pertama tahun 1988).

UU No. 7 Tahun 1984, (http:/ / www.lbh-apik.or.id/uu-7-84.htm).

Van Dijk, Teun A. 1997, "Discourse as interaction in society", di dalam: T.A. van Dijk (ed.), Discourse as social interaction. London: Sage.

Van Dijk, Teun A. 2004a. "Ideology and discourse analysis", (http:/ /www. discourses.org/Teun.html), diakses 12 Maret 2007.

Van Dijk, Teun A. 2004b. "Politics, ideology and discourse", (http:/ /www. discourses.org/Teun.html), diakses 12 Maret 2007.

Van Leeuwen, Theo. 1996. "The representation of social actors", di dalam: Caldas-Coulthard, Carmen Rosa, dan Malcolm Coulthard (ed), Texts and practices, hlm. 32-70. London: Routledge.

Wattie, Anna Marie. 2002. "Negara dan perempuan: makna hidup dan perjuangan Kartini untuk bangsa". Makalah, Peringatan Hari Kartini, Center for Population and Policy Studies, Gadjah Mada University, 21 April.

Wodak, Ruth dan Michael Meyer. 2001. Methods of critical discourse analysis. London: Sage. 
LAMPIRAN

26 Desember 2006 - 06:22 (Diposting oleh: em)

\section{Statement Bersama}

\section{"Poligami Adalah Diskriminasi dan Kekerasan Terhadap Perempuan dan Anak"}

Hari Ibu yang diperingati setiap tanggal 22 Desember merupakan tonggak sejarah bagi gerakan perempuan. Kongres Perempuan Indonesia I 1928 telah membicarakan dan mendiskusikan tentang masalah dan isu perempuan seperti pendidikan bagi kaum perempuan, nasib yatim piatu dan janda, perkawinan anak-anak, pembaharuan undang-undang perkawinan Islam, pentingnya meningkatkan harga diri di kalangan perempuan dan perkawinan paksa, juga tentang anti permaduan (anti poligami) dan nasionalisme.

Persoalan poligami dan diskriminasi terhadap kaum perempuan sudah lama menjadi momok bagi kaum perempuan. Penolakan terhadap poligami selalu berbenturan dengan budaya dan politik patriarki yang dijalankan dengan setia oleh pemerintah serta juga organisasi yang mengatasnamakan agama. Sejarah mencatat bahwa kegigihan kaum perempuan menolak poligami tidak bisa dibendung, November 1952 sembilan belas organisasi perempuan menyatakan menentang pemborosan uang negara untuk membayar poligami. Puncak penolakan terjadi 17 Desember 1953 saat berbagai organisasi perempuan menggelar aksi demonstrasi.

Saat ini 78 tahun sejak Kongres Perempuan Indonesia I 1928 kaum perempuan Indonesia masih berhadapan dengan persoalan sama yaitu poligami, yang disahkan dalam Undang-undang Perkawinan tahun 1974. UU tersebut menjustifikasi poligami meski dengan izin pengadilan, dan khususnya bagi PNS dengan izin pejabat. (PP 10/1983 dan PP 45/1990). Sebagai masalah yang bukan baru, poligami dipraktekan di Indonesia sejak beratus-ratus tahun lamanya mengakibatkan penderitaan pada kaum perempuan dan anak-anak. Karena itulah kami nyatakan bahwa:

\section{Poligami Mendiskriminasikan Kaum Perempuan, dan manifestasi Kekerasan Pada Perempuan dan Anak}

Budaya patriarki yang kuat membuat poligami tetap eksis. Sistem hukum dan politik yang didominasi laki-laki semakin memberi peluang poligami merajalela. Atas nama apapun poligami tak lebih legalisasi Penyaluran Nafsu. Semua adalah pengentalan dan pemapanan superioritas laki-laki, dan bahwa laki-laki adalah pemilik perempuan.

Undang-undang Perkawinan yang saat ini diterapkan oleh Pemerintah Indonesia secara nyata dan tegas mendiskriminasikan perempuan, salah satu pasalnya membolehkan suami untuk beristri lebih dari satu dengan syarat tertentu. Pasal tersebut merupakan pasal terfokus pada suami/laki-laki. Pasal 
ini jelas berkacamata patriarki, macho dan maskulin, sama sekali tak peduli pada istri, pada anak apalagi melindungi perempuan dan menjamin hak-hak istri/perempuan.

Poligami tak hanya terjadi di kalangan pejabat tetapi di semua lapisan masyarakat dalam segala macam strata sosial. Karena poligami merupakan keputusan sepihak dari suami ketika istri tidak mempunyai keberanian untuk menolak (dan tak punya kekuatan untuk melawan)-disebabkan: budaya patriarki, agama, ketergantungan ekonomi-maka kebanyakan poligami menyebabkan kekerasan pada perempuan dan anak baik fisik maupun psikis.

Fakta di seputar poligami menunjukkan banyaknya penderitaan yang timbul akibat poligami. Penderitaan tersebut dialami baik terhadap istri pertama juga istri yang lainnya serta anak-anak mereka. Dari 106 kasus poligami yang didampingi LBH-APIK selama kurun 2001 sampai 2005 memperlihatkan bentuk-bentuk kekerasan terhadap istri-istri dan anakanak mereka, mulai dari tekanan psikis, penganiayaan fisik, penelantaran istri dan anak-anak, ancaman dan teror serta pengabaian hak seksual istri. Sementara banyak poligami dilakukan tanpa alasan yang jelas. Sedangkan dari pemberitaan yang ada, poligami mendorong tingginya tingkat perceraian yang diajukan istri (gugat cerai) (Warta Kota, 12/4/03). (Selengkapnya lihat tabel Kasus Poligami LBH-APIK Jakarta).

\section{Poligami Semakin Memiskinkan dan Merendahkan Martabat Perempuan}

Banyak alasan dikemukakan untuk membenarkan praktek poligami, salah satunya untuk mengangkat harkat dan martabat perempuan khususnya perempuan miskin. Pernyataan tersebut justru semakin merendahkan martabat perempuan, karena berarti kaum perempuan tidak mempunyai mampu secara ekonomi, tidak mandiri sehingga perlu ditolong dengan cara dikawinkan.

Harkat perempuan tidak perlu diangkat. Apabila Negara dan Masyarakat telah memastikan bahwa tak ada yang lebih rendah dan lebih tinggi di antara perempuan dan laki-laki, melainkan setara. Dan sudah menjadi tanggung jawab dan tugas pemerintah untuk mendorong dan memberikan kesempatan bagi kaum perempuan, menyediakan dan memberikan fasilitas-fasilitas penunjang kemajuan kaum perempuan seperti: kesempatan pendidikan yang setara, menyediakan klinik kesehatan gratis, layak dan mudah terjangkau bagi ibu dan anak, merevisi semua undang-undang yang mendiskriminasikan kaum perempuan dan masih banyak lagi.

\section{Revisi UU Perkawinan Merupakan Salah Satu Upaya untuk Menghapuskan Poligami}

Sebagai negara yang telah melakukan ratifikasi CEDAW (The Convention on The Elimination of Discrimination Againts Women), Pemerintah Indonesia 
wajib memberikan perlindungan bagi perempuan dari berbagai bentuk diskriminasi, baik di lingkungan keluarga, masyarakat maupun negara. Pemerintah juga wajib membuat aturan-aturan yang menghapus diskriminasi dan kekerasan terhadap peremuan (Pasal 2 CEDAW). Oleh sebab itu revisi UU Perkawinan No. 1 Tahun 1974 dengan menghapus lembaga poligami yang disahkan selama ini, merupakan hal yang mutlak harus dilakukan segera.

Berdasarkan itu semua, kami menyerukan kepada semua pihak, khususnya pada pembuat kebijakan:

1). Agar segera membuat langkah-langkah kongkret untuk menghapuskan setiap bentuk diskriminasi dan kekerasan terhadap perempuan, khususnya di bidang perkawinan dengan mengurangi praktek poligami di masyarakat.

2). Mempercepat amandemen Undang-Undang Perkawinan No. 1 Tahun 1974.

3). Mengkritisi setiap tafsir ajaran agama yang diskriminatif terhadap perempuan dan sebaliknya perlu segera di sebarkan penafsiran ajaran agama yang lebih setara dan adil gender.

4). Menjadikan UU No. 7 Tahun 1984 sebagai acuan dalam penyusunan setiap kebijakan maupun dalam menyelesaikan kasus-kasus yang berkaitan dengan kehidupan kemasyarakatan, khususnya yang mengenai perempuan.

5). Menciptakan masyarakat yang bebas poligami dan bentuk-bentuk diskriminasi dan kekerasan lainnya terhadap perempuan dan anak.

Jakarta, 22 Desember 2006

Aliansi Pelangi Antar Bangsa (APAB), Aliansi Bhinneka Tunggal Ika (ANBTI), Bupera FSPSI Reformasi, Derap Warapsari, ICMC, ICRP, Insitut Perempuan, Kakilima, Kalyanamitra, Kapal Perempuan, KePPaK Perempuan, Kohati BP HMI, Koalisi Perempuan Indonesia untuk Keadilan dan Demokrasi (KPI)Jabotabek, LBH APIK Jakarta, LBH Jakarta, LKBH PeKa, Mitra Perempuan, Perempuan Mahardika, PKT RSCM, PP Fatayat NU, PP Muslimat NU, PSHK Indonesia, PERWATI, PGI Div.PA, Puan Amal Hayati, Rahima, Rekan Perempuan, Rumpun Gema Perempuan, Rumah Kita, Seknas KPI, Senjata Kartini (SEKAR), SBM Kerawang, Solidaritas Perempuan, SIKAP, SBMI, Yappika, Yayasan Kesehatan Perempuan (YKP), Yayasan Pulih, YATRIWI, YLBHI dan Individu-individu yang peduli

(Sumber: portal Indonesian Conference on Religion and Peace, bermoto Religions for Peace, http:/ / www.icrp-online.org/wmview.php?ArtID=211\&page=1, edisi 26, diposkan oleh em, 06:22, diakses pada 22 Maret 2007) 